\title{
SISTEM INFORMASI PERPANJANGAN DAN PELUNASAN GADAI EMAS BERBASIS WEB
}

\author{
Rudi Kusuma $^{1}$, Dedi Suhendro ${ }^{2}$ \\ ${ }^{1,2}$ Program Studi Komputerisasi Akuntansi AMIK Tunas \\ Jln. Jend. Sudirman Blok A No 1,2,3 Bangsa Pematangsiantar Sumatera Utara \\ ${ }^{1}$ Rudikusuma121@gmail.com \\ 22dedi.su@amiktunasbangsa.ac.id
}

\begin{abstract}
Abstrak - Gadai emas syariah merupakan salah satu fasilitas yang diberikan Bank Syariah Mandiri bagi nasabah yang ingin menggadaikan emas atau berinvestasi emas dengan prinsip syariah Islam, dengan menggunakan 2 teknik transaksi yaitu akad qardh dan akad ijarah. Dalam transaksinya, seringkali ditemukan beberapa masalah yaitu penghitungan taksiran emas baik perpanjangan maupun pelunasan karena harus mengikuti harga dasar emas yang terbaru dan media penyimpanannya yang kurang memadai. Hal ini cukup merepotkan karyawan karena harus mencari berkas nasabah yang lama di media penyimpanan. Oleh karena itu penulis memberikan solusi dengan membangun Sistem Informasi Perpanjangan dan Pelunasan Gadai Emas. Untuk mengembangkan sistem ini penulis menggunakan Relasi Antar Tabel (RAT), Entity Relationship Diagram (ERD), dan Data Flow Diagram (DFD) untuk melihat alur sistem. Untuk membangun sistem ini digunakan alat bantu pengembangan sistem yaitu Microsoft Visual Basic Net dan database MySQL.
\end{abstract}

Kata kunci : Sistem informasi, perpanjangan dan pelunasan, gadai emas, Microsoft Visual Basic Net, MySQL

\section{Pendahuluan}

Perbankan adalah segala sesuatu yang menyangkut tentang bank, mencakup kelembagaan, kegiatan usaha, serta cara dan proses dalam melaksanakan kegiatan usahanya sedangkan bank adalah badan usaha yang menghimpun dana dari masyarakat dalam bentuk simpanan dan menyalurkannya kepada masyarakat dalam bentuk kredit dan atau bentukbentuk lainnya dalam rangka meningkatkan taraf hidup rakyat banyak [1].

Pembiayaan berdasarkan prinsip Syariah adalah penyediaan uang atau tagihan yang dipersamakan dengan itu berdasarkan persetujuan atau kesepakatan antara bank dengan pihak lain yang mewajibkan pihak yang dibiayai untuk mengembalikan uang atau tagihan tabungan setelah jangka waktu tertentu dengan imbalan atau bagi hasi, prinsip Syariah adalah aturan perjanjian berdasarkan hukum Islam antara bank dan pihak lain untuk penyimpanan dana dan atau pembiayaan kegiatan usaha, atau kegiatan lainnya yang dinyatakan sesuai dengan syariah, antara lain pembiayaan berdasarkan prinsip bagi hasil (mudharabah), pembiayaan berdasarkan prinsip penyertaan modal (musharakahl, prinsip jual beli barang dengan memperoleh keuntungan (murabahah), atau pembiayaan barang modal berdasarkan prinsip sewa murni tanpa pilihan (ijarah), atau dengan adanya pilihan pemindahan kepemilikan atas barang yang disewa dari pihak bank oleh pihak lain (ijarah wa iqtina) [1]

Bank Syariah adalah Bank yang menjalankan kegiatan usahanya berdasarkan Prinsip Syariah dan menurut jenisnya terdiri atas Bank Umum Syariah dan Bank Pembiayaan Rakyat Syariah sedangkan Kantor Cabang Syariah adalah kantor cabang Bank Syariah yang bertanggung jawab kepada kantor pusat Bank yang bersangkutan dengan alamat tempat usaha yang jelas sesuai dengan lokasi kantor cabang tersebut melakukan usahanya [2].

Gadai Syari'ah (rahn) merupakan salah satu kategori dari perjanjian utang-piutang, yang mana untuk suatu kepercayaan dari orang yang berpiutang, maka orang yang berhutang menggadaikan barangnya sebagai jaminan terhadap utangnya itu [3] . Dalam dunia perbankan, kebanyakan gadai Syari'ah (rahn) yang dipakai adalah emas syariah sedangkan dalam Gadai Syari'ah ( $r a h n)$ emas syariah dalam bank syariah harus sesuai dengan aturan-aturan yang telah ditetapkan oleh pemerintah karena bank syariah merupakan lembaga keuangan yang diawasi oleh Bank Indonesia [4]. Gadai Syari'ah (rahn) itu merupakan suatu akad utang piutang 
dengan menjadikan barang yang memiliki nilai harta yang dijadikan sebagai jaminan kepercayaan, dengan menyandera nya untuk diserahkan sebagai jaminan secara hak, tetapi dapat diambil kembali sebagai tebusan [5]. Jadi kesimpulannya bahwa gadai Syari'ah (rahn) merupakan menahan barang jaminan baik yang bersifat materi atau manfaat tertentu sebagai jaminan atas pinjaman yang diterimanya. Teknik transaksinya menggunakan akad yaitu akad Qarhd dan akad Ijarah.

Akad Qarhd adalah pinjaman kebajikan/lunak tanpa imbalan atau sebagai pemberian harta, meminjamkan kepada orang lain yang dapat ditagih atau diminta kembali tanpa mengharapkan imbalan berdasarkan prinsip tolong-menolong [6].

Sedangkan akad Ijarah adalah suatu bentuk mueamalah yang melibatkan dua belah pihak, yaitu penyewa sebagai orang yang memberikan barang yang dapat dimanfaatkan kepada si penyewa untuk diambil manfaatnya [7].

Meskipun PT Bank Syariah Mandiri KC Pematangsiantar mengalami kemajuan yang cukup pesat namun dalam pengolahan data masih diolah menggunakan Microsoft Excel khususnya pada divisi gadai, masih memiliki masalah yaitu penghitungan taksiran emas yang terbaru, ketika nasabah melakukan perpanjangan masa gadai dan pelunasan terhadap emas yang telah digadai. Jangka waktu yang diberikan untuk melunasi emas yaitu 4 bulan dengan maksimal 2 kali perpanjangan, hal ini cukup merepotkan karena karyawan harus mencari berkas nasabah yang telah melakukan transaksi pada waktu yang lama pada media penyimpanan.

Maka penulis memberikan solusi dengan membangun Sistem Informasi Perpanjangan dan Pelunasan Gadai Emas. Penulis berharap sistem ini dapat memberi kemudahan bagi pegawai untuk membuat perpanjangan dan pelunasan gadai emas untuk menghindari terjadinya redundansi. Perhitungan taksiran, pembiayaan, dan biaya pemeliharaan yang terbaru berlaku ketika perpanjangan. Setelah tiba tanggal jatuh tempo maka nasabah dapat memperpanjang masa gadai jika belum memilki dana untuk melakukan pelunasan, atau bisa melunasi emas tersebut tanpa adanya perpanjangan. Dalam membangun sistem ini digunakan alat bantu pengembangan sistem yaitu Microsoft Visual Basic Net dan database MySQL.

\section{Metodologi Penelitian}

Metodologi yang digunakan dalam penulisan ini adalah metode perancangan sistem yang digunakan dalam membangun sistem, di antaranya membangun rancangan proses, rancangan input, rancangan output, rancangan database, rancangan sistem dan rancangan interface.

1. Rancangan Proses

a. Perancangan DFD Level 0

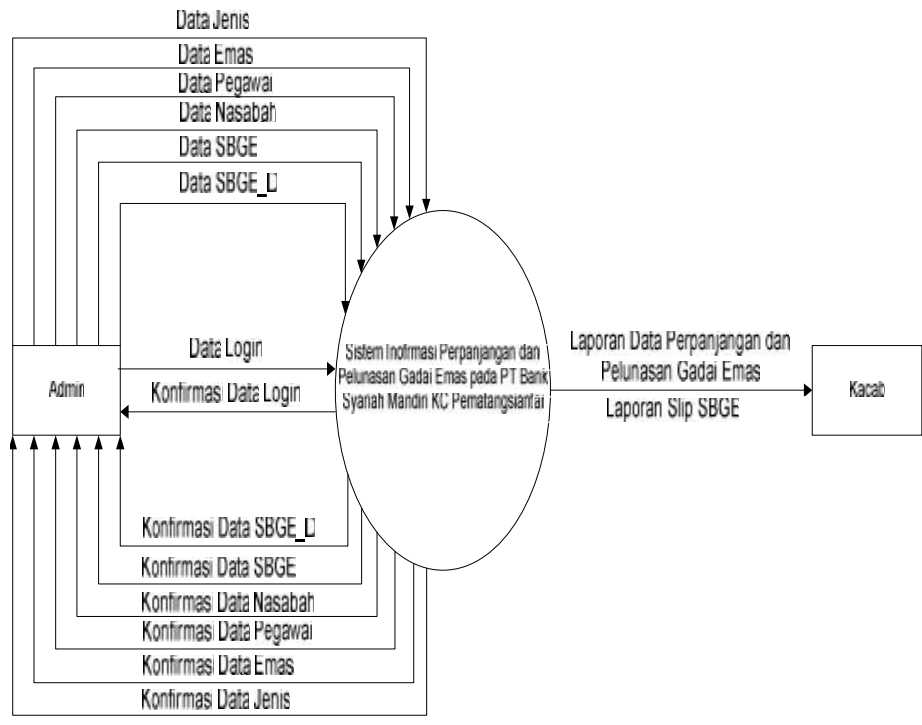

Gambar 1. Rancangan Proses DFD Level 0

b. Prancangan DFD Level 1

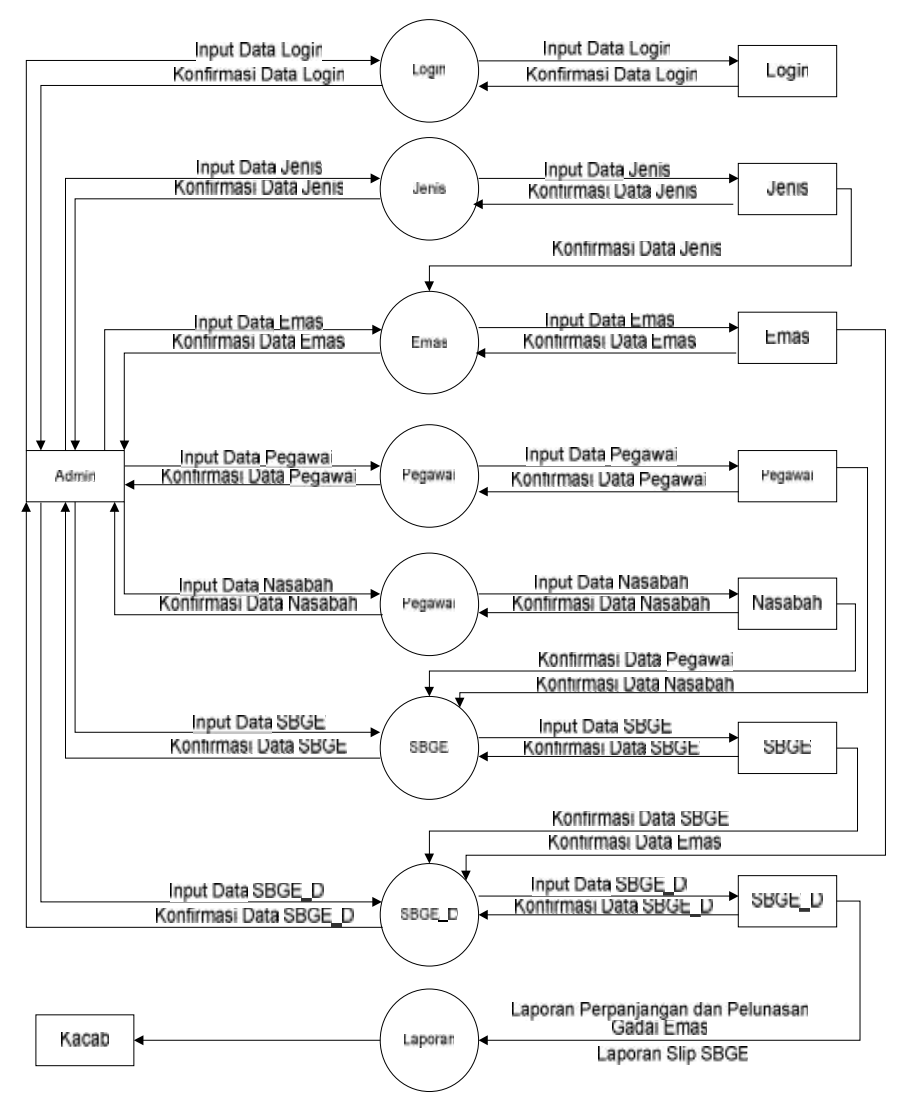

Gambar 2. Rancangan Proses DFD Level 1 


\section{Rancangan Masukan (Input)}

Rancangan masukan (input) merupakan rancangan yang dibuat untuk memasukkan data-data yang dibutuhkan ke dalam sistem. Berikut ini merupakan rancangan masukan (input) untuk Sistem Informasi Perpanjangan dan Pelunasan Gadai Emas pada PT Bank Syariah Mandiri KC Pematangsiantar.

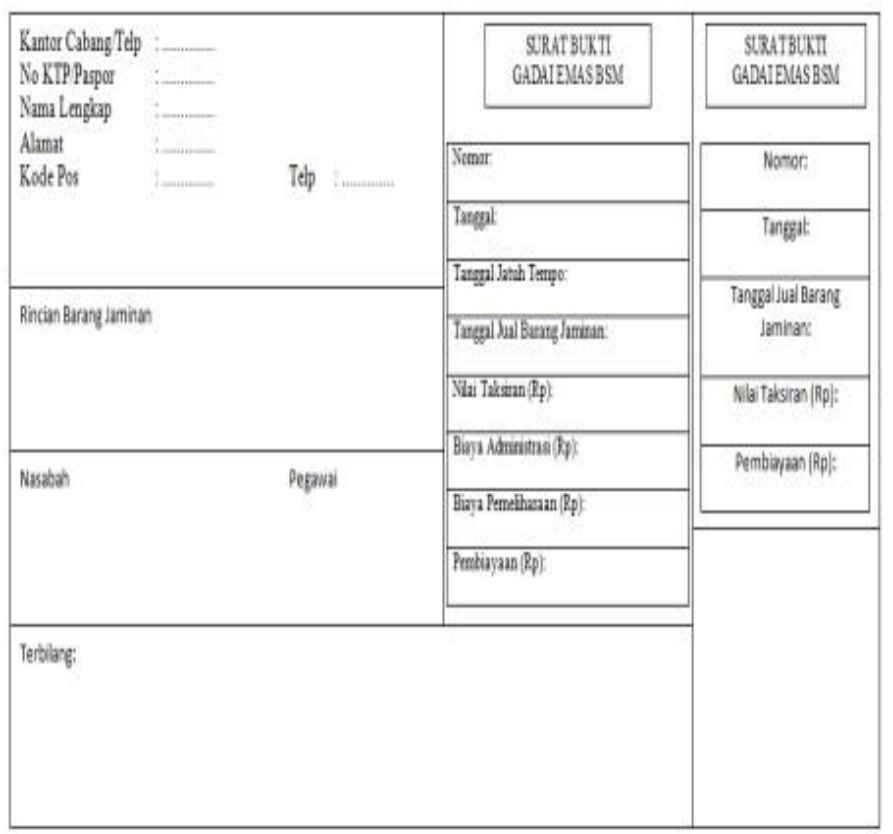

Gambar 3. Formulir Gadai Emas

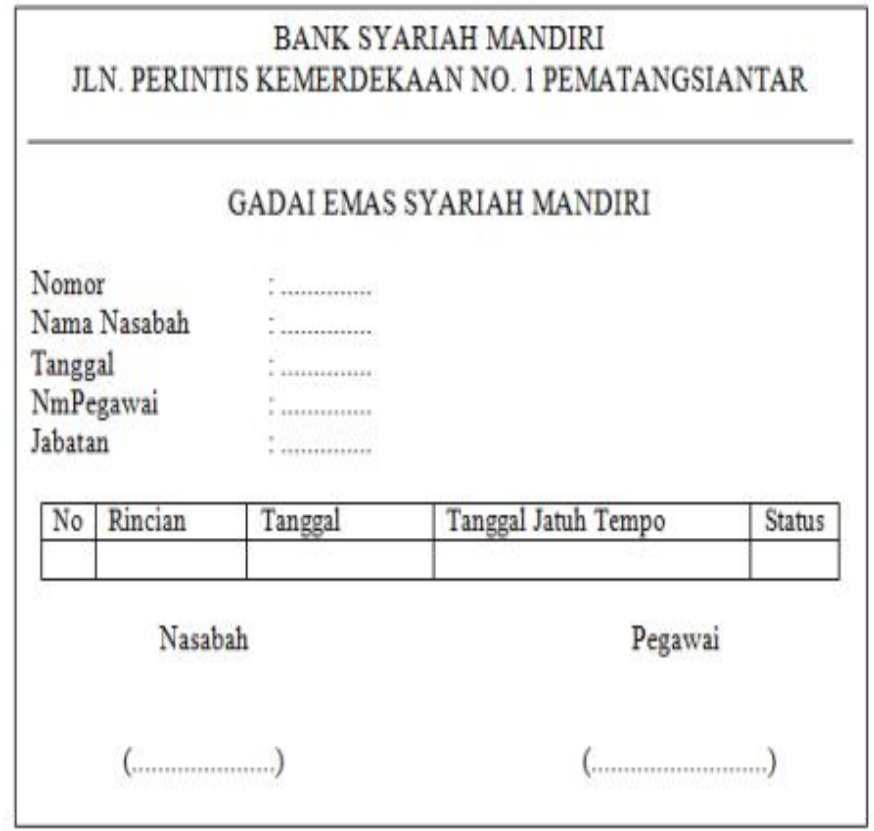

Gambar 4. Formulir Surat Bukti Gadai Emas

\section{Rancangan Keluaran (Output)}

Rancangan keluaran merupakan rancangan hasil yang dihasilkan dari sistem yang telah dirancang. Berikut adalah rancangan keluaran dari Sistem Informasi Perpanjangan dan Pelunasan Gadai Emas pada PT Bank Syariah Mandiri KC Pematangsiantar.

\begin{tabular}{|c|c|c|c|c|c|}
\hline & PERINTIS K & $\begin{array}{l}\text { UNIT } \\
\text { BANK SY } \\
\text { EMERDE }\end{array}$ & $\begin{array}{l}\text { IN (GADAI) } \\
\text { IAH MANDIRI } \\
\text { AN NO } 1 \text { PEM }\end{array}$ & ATANGS & ANTAR \\
\hline LAPOR & NDATA PEF & PANJAN & NDAN PELUN & IASAN G & DAI EMAS \\
\hline $\begin{array}{l}\text { IdPegal } \\
\text { NmPeg } \\
\text { Jabatan }\end{array}$ & i & $\ldots$ & & & \\
\hline Nomor & NmNasabah & Tanggal & Tglatuh Tempo & Rincian & Status \\
\hline & & & Pematangsian & tar, tangg & bulan-tahun \\
\hline & Kacab & & & Gadai Of & \\
\hline & asrah Siregar) & & & (Nazli Le & $\operatorname{tani})$ \\
\hline
\end{tabular}

Gambar 5. Rancangan Keluaran Laporan Perpanjangan dan Pelunasan Gadai Emas

4. Rancangan Database

a. Normalisasi

Normalisasi merupakan proses pengelompokkan elemen data menjadi tabel yang menunjukkan entitas sekaligus relasinya. Pada kasus ini penulis hanya membuat normalisasi hingga 3NF. Dan untuk menghasilkan hingga $3 \mathrm{NF}$ penulis mengambil sampel dari Formulir Gadai Emas.

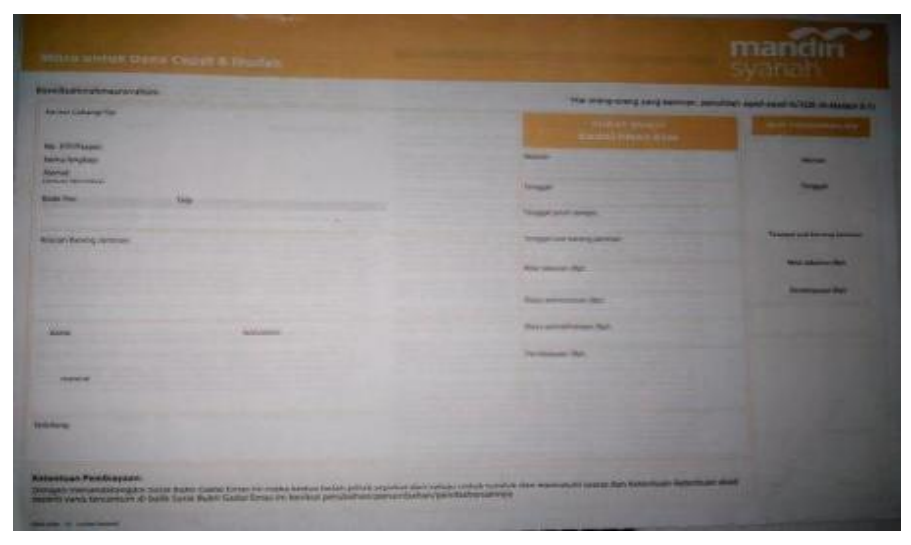

Gambar 6. Formulir Gadai Emas 


\begin{tabular}{|l|l|}
\hline KdJenis & Administrasi \\
NmJenis & Pemeliharaan \\
KdEmas & Biaya \\
KdJenis & Rincian \\
Bentuk & IdPegawai \\
IdPeganvi & KdEmas \\
NmPegawai & Status \\
Jabatan & NiK \\
Nomor & NmNasabah \\
NIK & TptLahir \\
Tanggal & TglLahir \\
TglJatuhTempo & Jenkel \\
TglJualBrgJaminan & Alamat \\
Berat & RT/RW \\
Karat & KeVDesa \\
HDE & Kecamatan \\
Nilai & KdPos \\
Jumlah & Telp \\
Taksiran & Pekerjaan \\
\hline
\end{tabular}

Gambar 7. 1NF (Normal Form Ke 1)

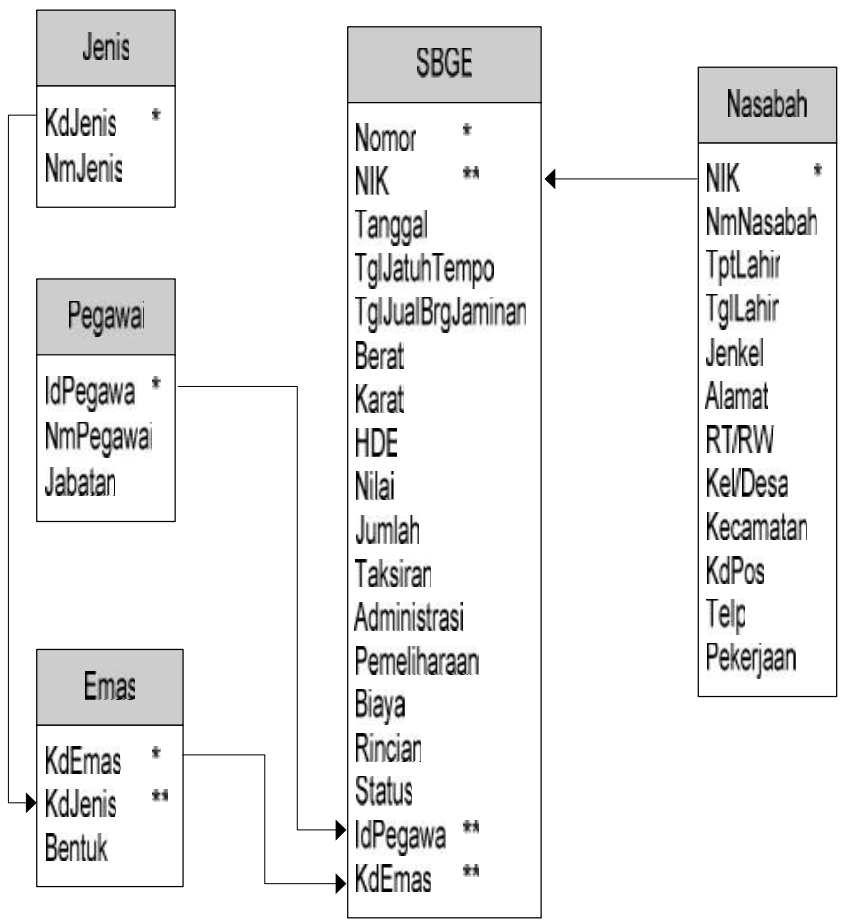

Gambar 8. 2NF (Normal Form Ke 2)

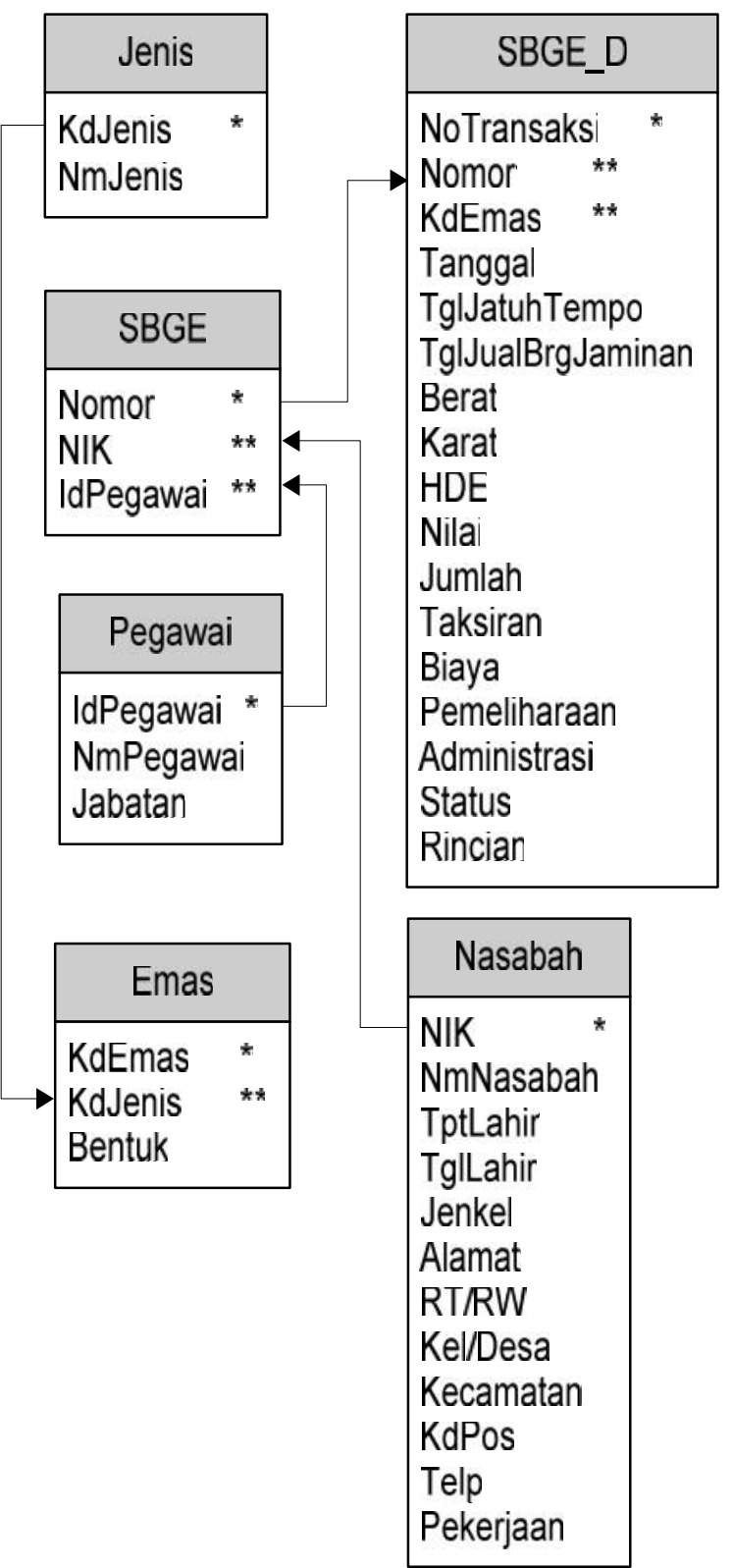

Gambar 9. Bentuk 3NF

\section{Entity Relationship Diagram}

Bentuk dari Entity Relational Diagram dari Sistem Informasi Perpanjangan dan Pelunasan Gadai Emas PT Bank Syariah Mandiri KC Pematangsiantar adalah seperti pada gambar di bawah ini. 


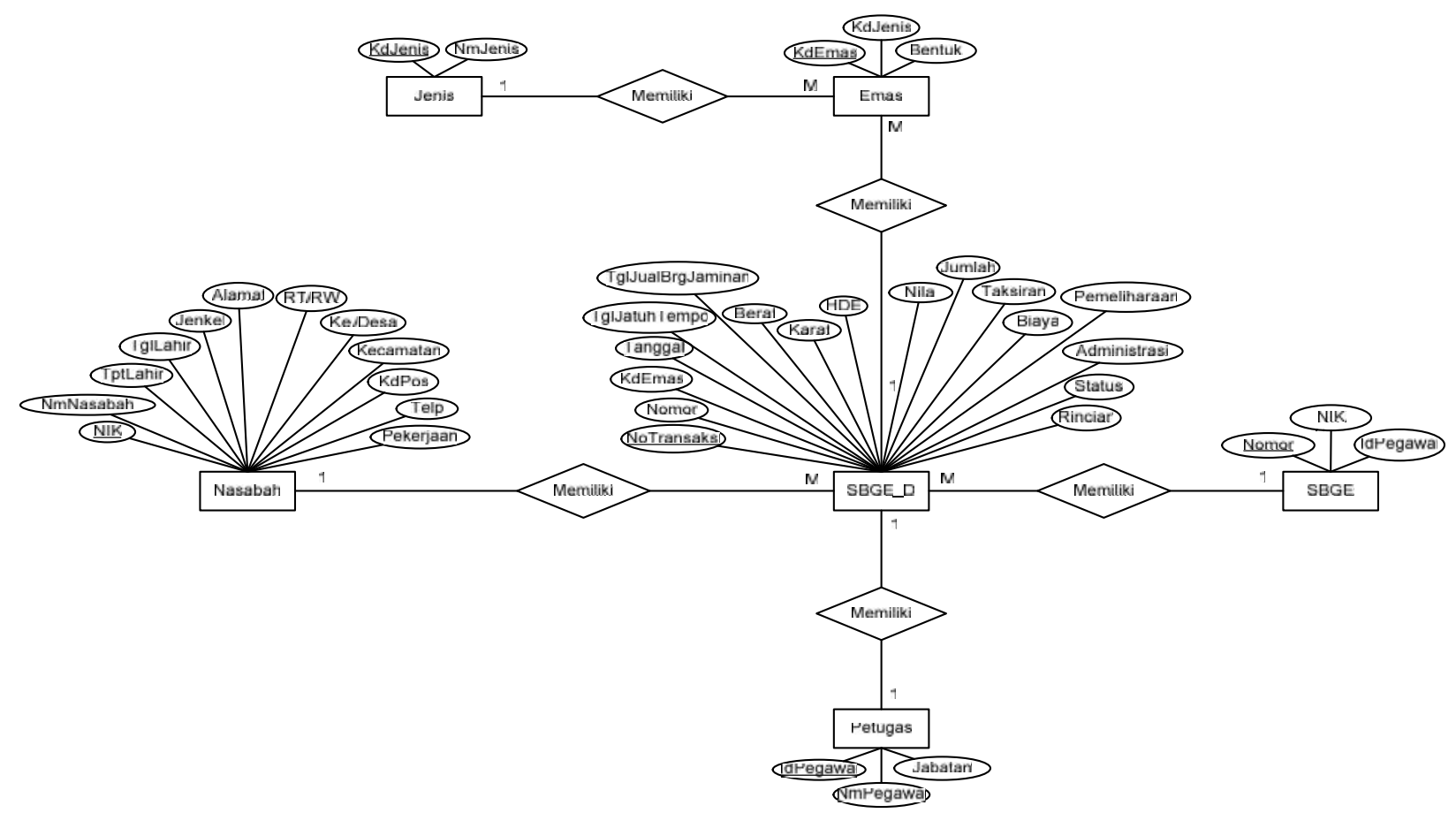

Gambar 10. Entity Relational Diagram

\section{Rancangan Sistem}

Rancangan sistem merupakan rancangan dari Sistem Informasi Perpanjangan dan Pelunasan Gadai Emas pada PT Bank Syariah Mandiri KC Pematangsiantar yang dirancang dalam bentuk bagan berikut ini.



Gambar 11. Diagram HIPO

\section{Rancangan Interface}

Perancangan Interface merupakan suatu kegiatan membuat desain teknis berdasarkan evaluasi yang telah dilakukan pada kegiatan analisis. Perancangan Interface bertujuan untuk memenuhi kebutuhan kepada pemakai sistem dan memberikan gambaran yang jelas dari sistem yang akan dibangun menggunakan Visual Studio2010 dan MySQL dalam bentuk form.

a. Perancangan Form Login

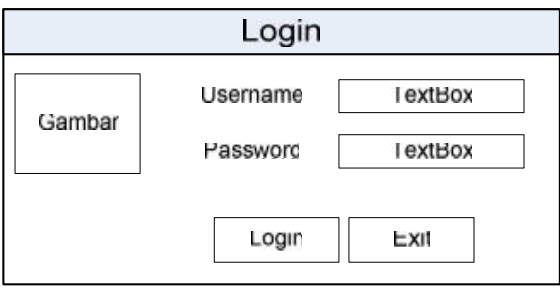

Gambar 12. Perancangan Form Login

b. Perancangan Form Utama 


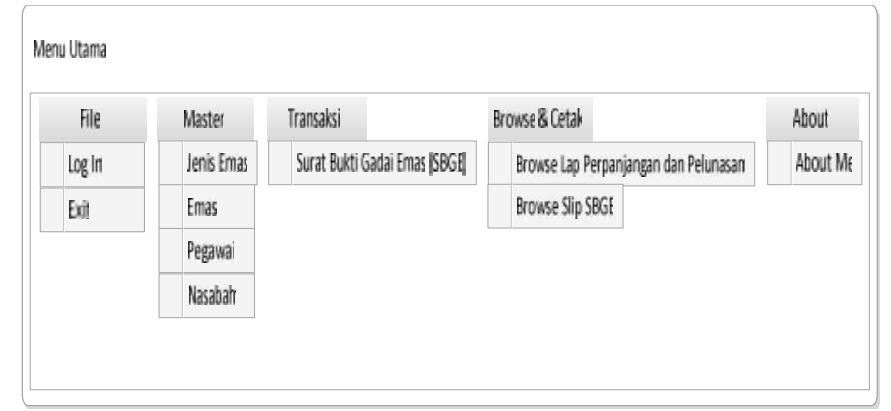

Gambar 13. Perancangan Form Utama

c. Peracangan Form Jenis

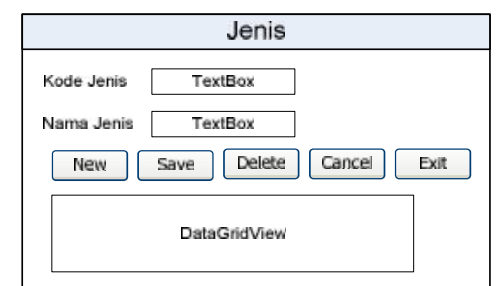

Gambar 14. Perancangan Form Jenis

d. Peracangan Form Emas

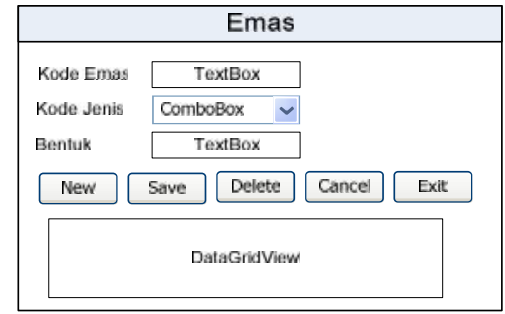

Gambar 15. Perancangan Form Emas

e. Peracangan Form Pegawai

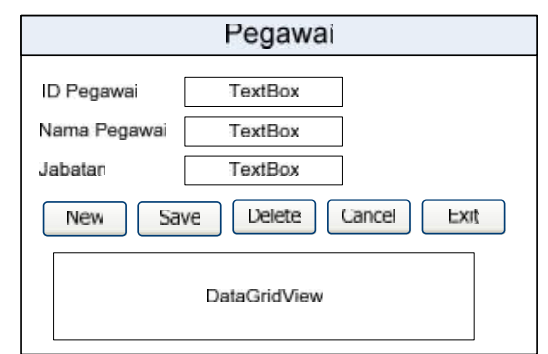

Gambar 16. Perancangan Form Pegawai

f. Perancangan Form Nasabah

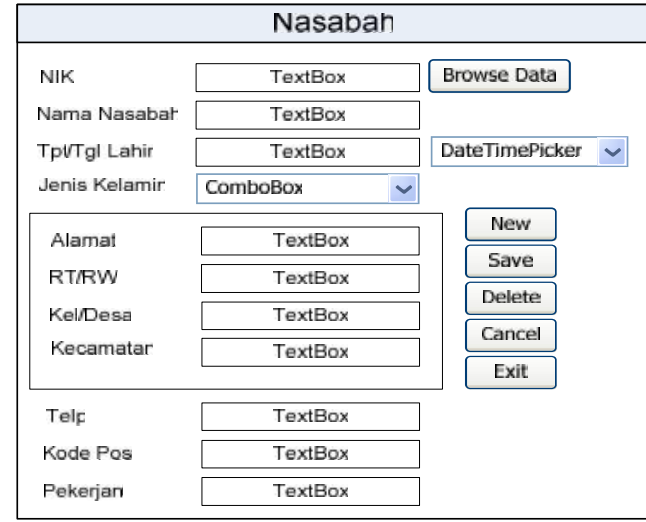

Gambar 17. Perancangan Form Nasabah

g. Perancangan Form Surat Bukti Gadai Emas

\begin{tabular}{|c|c|c|c|c|c|c|c|c|}
\hline \multicolumn{9}{|c|}{ Form Surat Bukti Gadai Emas } \\
\hline \multirow{2}{*}{\begin{tabular}{|l|} 
No Transaksi \\
Nasabat
\end{tabular}} & Tentio & \multirow{2}{*}{$\begin{array}{l}\text { Nemar } \\
v p\end{array}$} & \multirow[t]{2}{*}{ Tentian } & & & \multirow{2}{*}{$\begin{array}{l}\text { Targga } \\
\text { Peganai }\end{array}$} & \multirow{2}{*}{\begin{tabular}{|l} 
DateTimeP ibser \\
Combobcx \\
\end{tabular}} & v \\
\hline & Controbex & & & & & & & $v$ \\
\hline \multicolumn{9}{|c|}{ 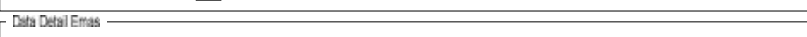 } \\
\hline Status & Conbobos & $\sqrt{v}$ & & \multirow{2}{*}{$\begin{array}{l}\text { Tgl Jatuh Tempo } \\
\text { Tgl Jual Barang Jaminar }\end{array}$} & DateTimePcher & $v$ & & \\
\hline Jenis & Conbobox & v & & & an DateTmePicher & v & & \\
\hline Emas & Tentiati & Teristi & $m$ & \multirow{4}{*}{$\begin{array}{l}\text { Taksiran } \\
\text { Pembiayaant } \\
\text { Rincian }\end{array}$} & Tentiow & \multirow{5}{*}{$\begin{array}{l}\text { Pemeliharaan } \\
\text { Administras }\end{array}$} & \multicolumn{2}{|l|}{ Tentisis } \\
\hline Berat & Ten:Bo & Kara & Tentige & & Tentiva & & \multicolumn{2}{|c|}{ Tetitise } \\
\hline HDE & Tetisu & Jumah: & Tention & & \multirow{2}{*}{ Tentisw } & & & \\
\hline Nilai Emas & Tenga & & & & & & & \\
\hline \multicolumn{2}{|c|}{ Isi Nomor atau Nama Nasabah } & & Ten:Ba & & & & & \\
\hline \multicolumn{9}{|c|}{ cenagndvioa } \\
\hline Now & Detest & Cantes & Exil & & & & & \\
\hline
\end{tabular}

Gambar 18. Perancangan Form Surat Bukti Gadai Emas

h. Perancangan Form Browse Laporan Perpanjangan dan Pelunasan Gadai Emas

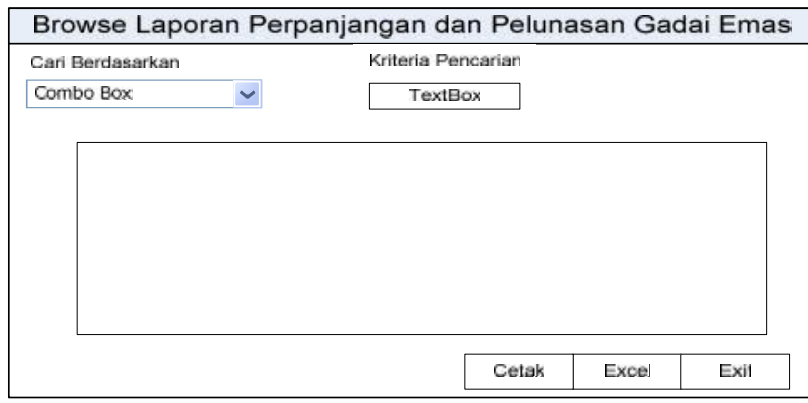

Gambar 19. Perancangan Form Browse Perpanjangan dan Pelunasan

Gadai Emas 
i. Perancangan Form Browse Slip Surat Bukti Gadai Emas

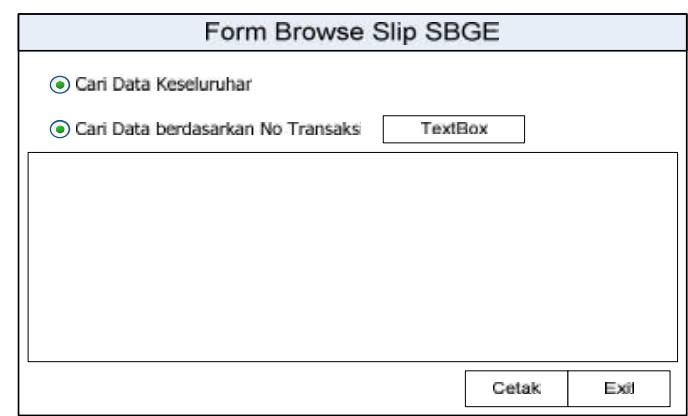

Gambar 20. Perancangan Form Browse Slip Surat Bukti Gadai Emas

j. Perancangan Slip Surat Bukti Gadai Emas

\begin{tabular}{|c|c|c|}
\hline \multicolumn{2}{|c|}{$\begin{array}{c}\text { UNIT RAHN (GADAI) } \\
\text { BANK SYARIAH MANDIRI } \\
\text { Jln. Perintis Kemerdekaan No. 1 Pematangsiantar }\end{array}$} & Logo \\
\hline \multicolumn{3}{|c|}{ SLIP SURAT BUKTI GADAI EMAS } \\
\hline No Transaksi : & Tanggal & \\
\hline $\begin{array}{l}\text { Nomor } \\
\text { NIK } \\
\text { NmNasabah } \\
\text { Alamat } \\
\text { TgIJatuhTempo } \\
\text { Taksiran } \\
\text { Biaya } \\
\text { Pemeliharaan } \\
\text { Administrasi } \\
\text { Status }\end{array}$ & & \\
\hline NmNasabah & Pegawai & \\
\hline$(\ldots+-1-1-1-1)$ & ................. & ....) \\
\hline
\end{tabular}

Gambar 21. Perancangan Slip Surat Bukti Gadai Emas

\section{HASIL DAN PEMBAHASAN}

1. Menu Utama

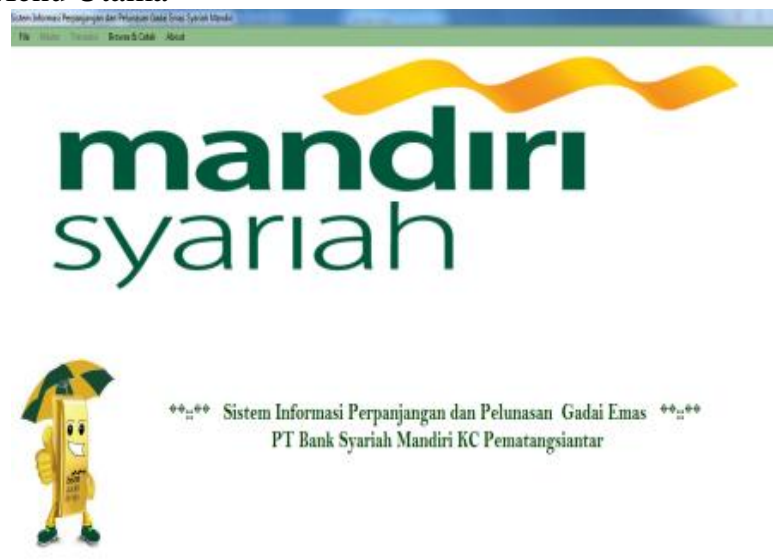

Gambar 22. Menu Utama

\section{Input Form Login}

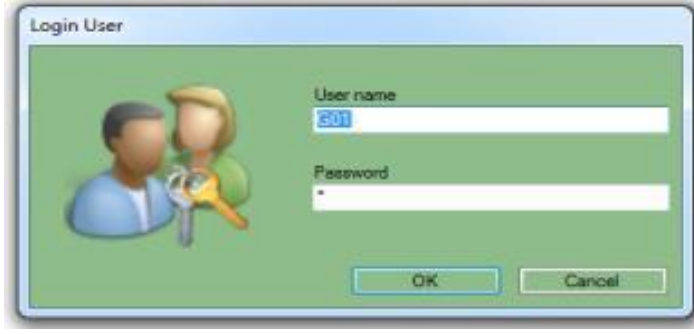

Gambar 23. Input Form Login

3. Input Form Jenis

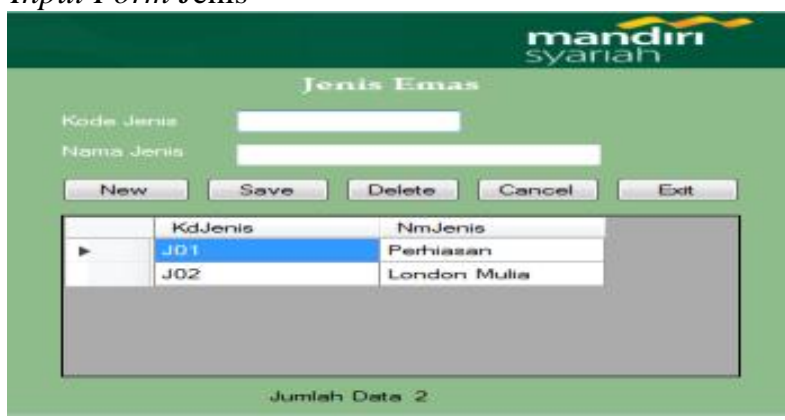

Gambar 24. Input Form Jenis

4. Input Form Data Emas

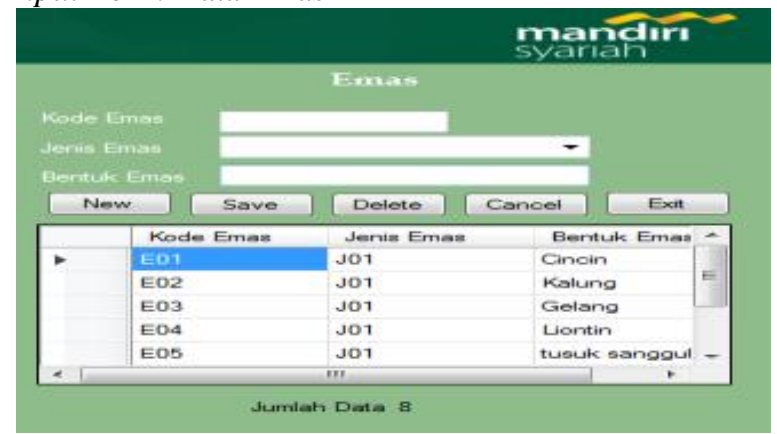

Gambar 25. Input Form Emas

5. Input Form Pegawai

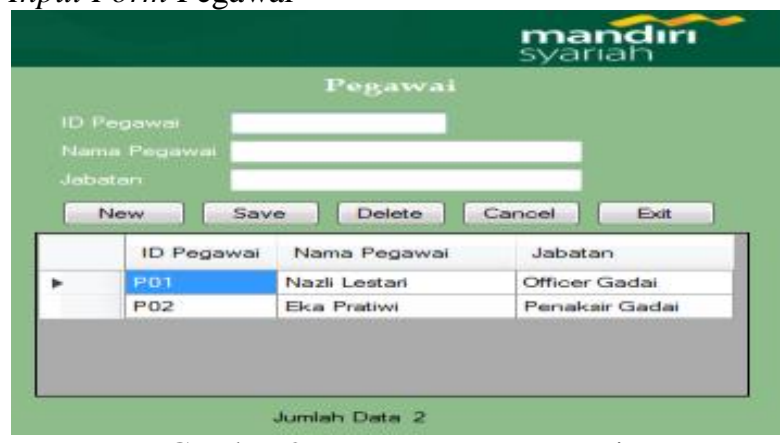

Gambar 26. Input Form Pegawai

6. Input Form Nasabah 


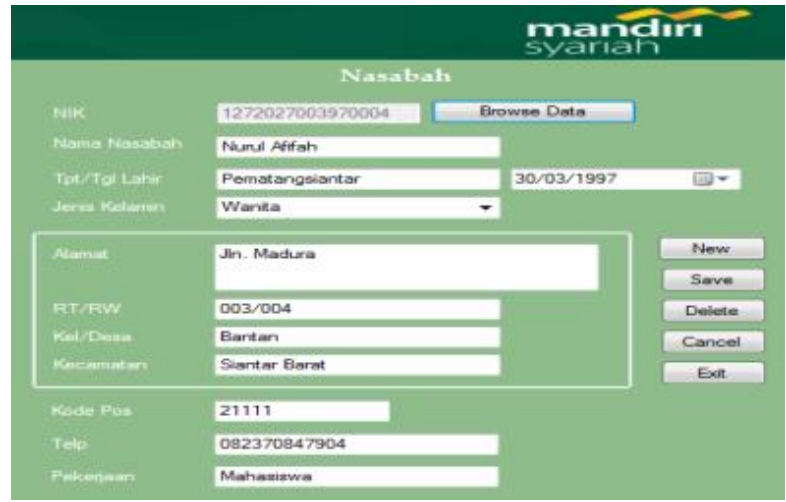

Gambar 27. Input Form Nasabah

7. Input Form Surat Bukti Gadai Emas

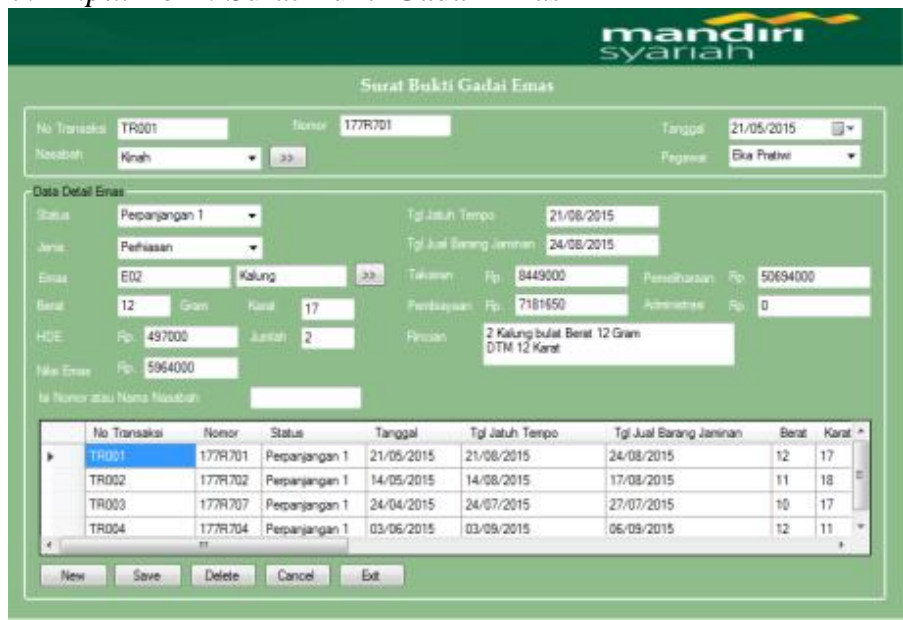

Gambar 28. Input Form Surat Bukti Gadai Emas

8. Output Laporan Perpanjangan dan Pelunasan Gadai Emas
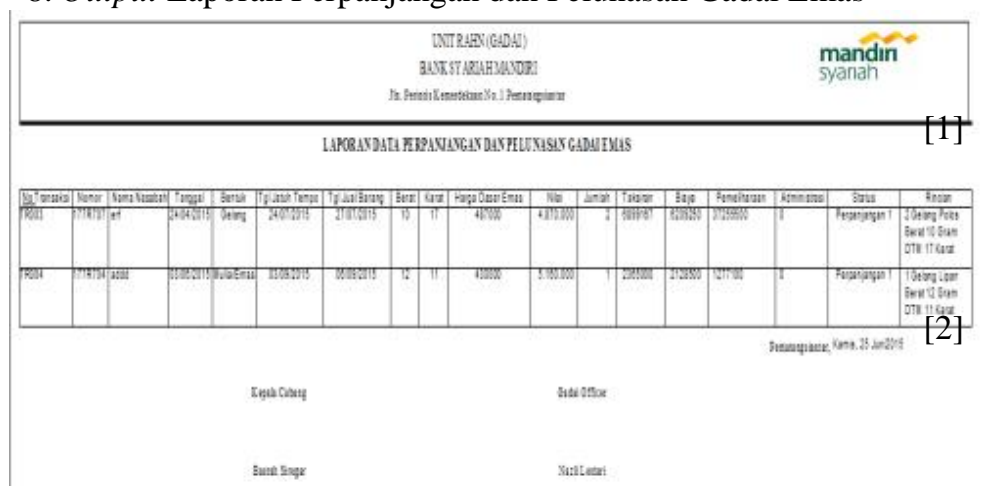

Gambar 29. Output Laporan Perpanjangan dan Pelunasan Gadai Emas

9. Output Slip Surat Bukti Gadai Emas

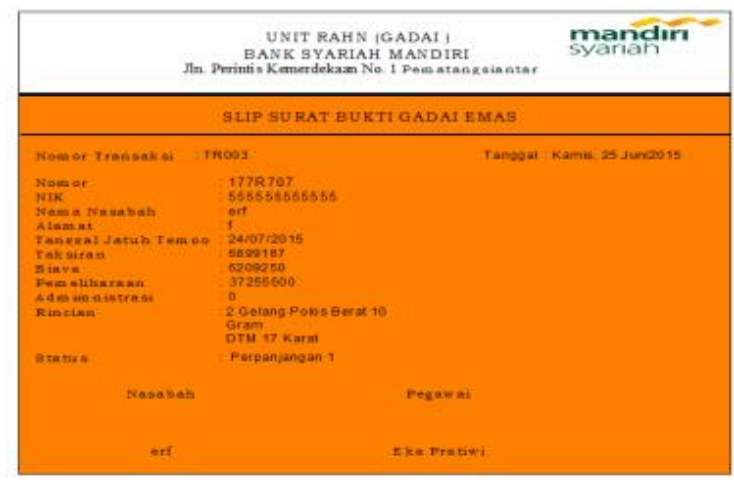

Gambar 30. Output Slip Surat Bukti Gadai Emas

\section{KESIMPULAN}

Berdasarkan penelitian yang dilakukan penulis, maka penulis menyimpulkan bahwa:

1. Perancangan Sistem Informasi Perpanjangan dan Pelunasan Gadai Emas pada PT Bank Syariah Mandiri diperlukan desain input yang berisikan rancangan input ke sistem, desain proses yang berisikan Entity Relationship Diagram (ERD) untuk menggambarkan tabel yang diperlukan, Relasi Antar Tabel (RAT) untuk merelasikan tabel, Data Flow Diagram (DFD) untuk alur data, dan Flowchart alur kerja dari sistem dari sistem, desain output yang berisikan laporan yang merupakan hasil akhir dari rancangan sistem ini.

2. Transaksi pada form Surat Bukti Gadai Emas dan laporan yang dihasilkan, maka dapat diketahui perhitungan dari kedua transaksi baik perpanjangan maupun pelunasan.

3. Melalui laporan dapat di lihat status transaksi nasabah yang mengalami keterlambatan atau jatuh tempo.

\section{REFERENSI}

A. Muttalib, (2016). "Implikasi Gadai Syari'ah terhadap Kesejahteraan Masyarakat kota Praya (Studi Kasus di Pegadaian Syari'ah Cabang Praya)," JIME, vol. 2, no. 2, pp. 291-296, 2016.

E. K. Lubis and D. Suhendro, (2019). "Rancang Bangun Aplikasi Data Permohonan Gadai Emas pada PT Bank Syariah Mandiri KCP Kota Perdagangan Kabupaten Simalungun," Indones. J. Netw. Secur., vol. 8, no. 4, pp. $1-7,2019$.

[3] Rustam, (2011). "Pemanfaatan Barang Gadai oleh Pemegan Gadai dalam Perspektif Hukum Islam," UIN Alauddin Makassar, 2011.

[4] M. . H. Muklis, S.E. and S. E. S. Risti Wulandari, (2017). "Pengaruh Produk Jasa Gadai (Rahn) dengan Akad Qard dan Ijarah terhadap Kepeminatan Masyarakat untuk 
Berbank di Bank Syariah Mandiri," J. Ekon. dan Perbank. Syariah, pp. 37-63, 2017.

[5] U. K. Khotimah, (2017). “Analisis Hukum Islam terhadap Pelaksanaan Akad Ijarah pada Pembiayaan Multijasa di PT. BPRS PNM Binama Semarang," Islam Negeri Walisongo, 2017.

[6] "Undang-Undang Republik Indonesia No 10 Tahun 1998," 1998.

[7] “Undang-Undang Republik Indonesia No 21 Tahun 2008 tentang Perbankan Syariah,”. 